Article

\title{
Knowledge Management Practices and Innovation Outcomes: The Moderating Role of Risk-Taking and Proactiveness
}

\author{
Gema García-Piqueres ${ }^{\mathbb{D}}$, Ana-M. Serrano-Bedia ${ }^{\mathbb{D}}$ and Marta Pérez-Pérez * $\mathbb{D}$ \\ Business Administration Department, University of Cantabria, 39005 Santander, Cantabria, Spain; \\ gema.garcia@unican.es (G.G.-P.); ana.serrano@unican.es (A.-M.S.-B.) \\ * Correspondence: perezpm@unican.es; Tel.: +34-942-203925
}

Received: 28 August 2019; Accepted: 20 September 2019; Published: 26 September 2019

check for updates

\begin{abstract}
This study, by the application of a linear regression by ordinary least squares (OLS), aimed to explore the relationships between knowledge management practices (KMP) and innovation outcomes (product, process, organizational, and commercial), and how they can be moderated by two dimensions of the entrepreneurial orientation (proactiveness and risk taking). This empirical study used survey data from a sample of 288 Spanish family small and medium enterprises (SMEs). The results revealed a positive effect of all the KMPs studied for at least one of the innovation variables studied. Regarding the moderating effect of proactiveness and risk taking on the KMP-innovation outcomes relationship, proactiveness negatively moderated the relationship between knowledge creation and product/process innovation. Moreover, a positive moderating effect was found for the case of knowledge application and process innovation. With regard to risk taking, the evidence found was mixed, and confirmed for some KMPs and all the innovation measures, with the exception of process innovation. The only positive moderating effect found was for knowledge storage and product innovation, whereas, contrary to expected, a negative moderating effect was found for knowledge creation, transfer, and application practices and commercial, product, and organizational innovations, respectively.
\end{abstract}

Keywords: family firm; knowledge; innovation outcomes; risk-taking; proactiveness

\section{Introduction}

At present, the advent of the "new knowledge economy" has led to the consideration of knowledge as one of the most important organizational resources to develop sustainable competitive advantages (Biscotti et al. 2018; Mustafa et al. 2016) and obtain superior organizational performance and success (Spender 1996; Schiuma et al. 2012; Del Giudice and Maggioni 2014; Lotti Oliva 2014). Thus, firms are paying increasing attention to knowledge management (KM) (Calvo-Mora et al. 2016; Hussinki et al. 2017), which is defined as "the organized process of creating, capturing, storing, disseminating, and using knowledge within and between organizations" (Jayasingam et al. 2013, p. 256).

Given this situation, this paper had two aims. First, it provided evidence about knowledge management practices (KMP), which are defined as a set of management activities related to knowledge resources to achieve organizational goals (Stanovcic et al. 2015), and their influence on firms' innovation outcomes, which are identified as a critical factor for the continued growth and vitality of organizations and economies (Garud et al. 2013). Moreover, and considering that KMP design and implementation is a difficult task for managers conditioned by the characteristics of the organization and its members (Argote et al. 2003; Bojica et al. 2017), this paper focused on family firms (FF). The relevance to explore this singular context has been justified by several authors (Andersén 2015; Gupta and Bhattacharya 2016; Fang et al. 2018) by suggesting that in family firms, the identity overlap between the family and the firm 
tends to affect the KM process (Biscotti et al. 2018). Specifically, research on innovation management in FF has shown that these firms are usually characterized by adopting an internal-oriented approach, investing less in research and development (R\&D) (De Massis et al. 2013; Duran et al. 2016; Roed 2016), and being more reluctant to acquire new technology (Kotlar et al. 2013). Consequently, these firms are expected to have less capacity to collect and store knowledge (Andersén 2015; DiPasquale and McInerney 2010). In addition, FFs share certain characteristics, such as strong ties, cohesiveness, and emotional attachment among their members, which may contribute to their capacity to share and transfer knowledge-based resources (Zahra et al. 2007; Chirico and Salvato 2016).

Secondly, this paper analyzed the moderating influence of entrepreneurial orientation (EO) on the KMP-innovation outcomes relationship. More precisely, we focused on two EO dimensions: risk taking and proactiveness. EO, which can be defined as "the strategy-making processes that provide organizations with a basis for entrepreneurial decisions and actions" (Rauch et al. 2009, p. 762), has attracted increasing scholarly attention in the family business field, "leading to a rich, complex and somewhat fragmented body of research" (Hernández-Linares and López-Fernández 2018, p. 318). Despite this interest, several aspects of EO research in FFs remains mostly absent in the literature, such as the role of $\mathrm{EO}$ and its dimensions as moderating variables on the relationships between different resources, processes, and firm performance (Serrano-Bedia et al. 2018b). In this regard, the limited evidence indicates that EO positively moderates the effect of corporate social responsibility (CSR) on FFs' performances, enhancing this effect (Hernández-Perlines and Rung-Hoch 2017). To reach these objectives, we collected data from a survey of Spanish family firms.

Our work makes at least three contributions to the literature. We first contributed to previous literature by deepening the study of the relationship between two key constructs in management literature-KMP and innovation-by considering a broad range of KMP and innovation outcomes. Secondly, we added to the limited research on KM in the FF context (Nieto et al. 2015; Chirico and Salvato 2016; Serrano-Bedia et al. 2016) by empirically exploring how KM practices contribute to FF innovation outcomes. Finally, our study is pioneering in research of the moderating influence of two EO dimensions on the KMP-innovation outcomes relationship in an effort to expand the limited existing knowledge about this subject. This also represents a theoretical contribution to the KM perspective due to the unique nature of family firms. By addressing these research gaps, our study also has a practical implication for family firms, which should have awareness of the importance of knowledge as a firm's advantage.

The remainder of this paper is organized as follows: Section 2 establishes the hypotheses associating the use of different KM practices with innovation performance, and examines the degree to which these relationships are moderated by two EO dimensions. Section 3 presents the methods used in this empirical study. The subsequent section presents the empirical findings and discussion. Finally, we present the conclusions, implications, and limitations of the research.

\section{Literature Review and Hypotheses}

\subsection{KMP and Innovation Outcomes}

KMP is a key element in fostering innovation (Lee et al. 2013; Yusr et al. 2017). This is because innovation consists of the successful exploitation of new ideas (Amabile et al. 1996), and therefore, is usually considered a direct outcome of KM effectiveness (Du Plessis 2007). For this reason, managers aiming to achieve competitive advantages based on firms' innovative outcomes should establish the ideal contextual conditions to promote and encourage the organization's use of KMP (Donate and de Pablo 2015).

The literature analyzing the KMP-innovation relationship has explored the direct effect of diverse KMPs on innovation, mostly finding a positive relationship (e.g., Li et al. 2009; Andreeva and Kianto 2011; Alegre et al. 2013; Lee et al. 2013; Kianto et al. 2014; Donate and de Pablo 2015; Yusr et al. 2017). Despite this general result, research exploring KM in the FF context (Zahra et al. 2007; Chirico and 
Salvato 2008; Patel and Fiet 2011; Cunningham et al. 2016; Letonja and Duh 2016) is still scarce and partial, and practically none of the existing studies exploring KM in FF analyzed its effects on firm innovation (Serrano-Bedia et al. 2018a), leaving an evident a gap in this field. The only exceptions identified are the studies of Serrano-Bedia et al. (2016); Kallmuenzer and Scholl-Grissemann (2017), and Serrano-Bedia et al. (2018a). Serrano-Bedia et al. (2016) reported a negative moderating effect of CEO tenure, CEO-founder duality, and family involvement on the positive relationship between the use of various types of knowledge sources and innovation performance. Kallmuenzer and Scholl-Grissemann (2017), for their part, investigated the effect of knowledge internalization and external knowledge on the technological and management innovation of family businesses. Finally, Serrano-Bedia et al. (2018a) found that being a family firm negatively moderated the positive link between creation and the storage of new knowledge and innovation, and positively moderated the negative (but non-significant) link between knowledge transfer and innovation.

In this paper, and in line with Donate and de Pablo (2015), we analyzed four types of KMP: creation, storage, transfer, and application. Knowledge creation practices relate to the internal development of new knowledge content or replacing existing content in the organization's explicit or tacit knowledge pool (Alavi and Leidner 2001), typically through R\&D activities. Knowledge storage practices include organization, structuring, and the retrieval of organizational knowledge, which allow the firm to maintain an organizational memory (Donate and de Pablo 2015). Knowledge transfer activities are those that permit organizational members to share, disseminate, and replicate information, spreading this information through communication channels (Alavi and Leidner 2001). Finally, knowledge application practices refer to the integration and application of existing knowledge to develop an organizational capability that makes decision making and problem solving easier and more effective for the firm (Grant 1996; Zack et al. 2009). The hypotheses about the effects of each of these practices on innovation performance are presented below.

\subsubsection{Creation}

In-house knowledge creation may place firms in a better position to develop new resources and capabilities that allow them to obtain and maintain positive returns over time on their innovation activities (Roberts and Amit 2003; Katila 2002; Katila and Ahuja 2002). This internal accumulation of knowledge reduces dependence on the external environment (Beneito 2003) and makes firms better able to develop the necessary absorptive capacity for an effective combination of in-house and external knowledge (Cohen and Levinthal 1990), thus achieving better innovative performance in a firm (Zahra and George 2002).

Despite these theoretical considerations and the empirical evidence confirming a positive effect of knowledge creation on firm innovation (Alegre et al. 2013; Lee et al. 2013; Andreeva and Kianto 2011; Chen et al. 2010; Donate and de Pablo 2015), theoretical arguments about the negative effects derived from the use of in-house generated knowledge were also identified in the literature. Thus, firms successfully generating in-house knowledge are less likely to be open to new external knowledge (Kim and Song 2007), and tend to focus on areas closely related to pre-existing knowledge (Eisenhardt and Martin 2000), which can, in turn, negatively influence future technological innovation (Mascarenhas 1985). Moreover, internal knowledge creation consumes substantial resources (Li and Atuahene-Gima 2001; Van de Ven 1986) and requires the development of new capabilities to generate and appropriate the benefits of innovation (Branzei and Vertinsky 2006; Sethi and Seth 2009; Thornhill 2006).

In family firms, intergenerational involvement in management and strategy may result in the development of a wider set of knowledge creation practices that could generate innovation outcomes (De Clercq et al. 2013), while parental altruism may hinder the inclusion of human resources that could, with new creative knowledge and intangible skills, promote innovation (Chen and Hsu 2009). In addition, some specific behavioral characteristics of family firms, such as risk aversion, could limit the benefits of in-house generated knowledge for these firms. Regarding the available empirical evidence, previous studies about the effect of knowledge creation practices on family firms' innovation 
performance reported a positive relationship (Serrano-Bedia et al. 2016), whereas other research showed that being a family firm negatively moderated the positive link between the creation of new knowledge and innovation (Serrano-Bedia et al. 2018a). Consequently, we propose the following hypothesis:

Hypothesis 1 (H1). Knowledge creation management practices contribute to improvements in family firms' innovation outcomes.

\subsubsection{Storage}

Knowledge storage practices allow firms to improve the quality of the knowledge stored and its application and transfer throughout the organization by removing or substituting the less relevant or obsolete knowledge (Donate and de Pablo 2015). This codified knowledge accumulated in repositories enables a wider spread of knowledge and its more effective exploitation, thus improving the execution of the innovation process, leading to better innovation results (Purvis et al. 2001; Argote and Ingram 2000). For their part, Ren et al. (2006) empirically showed how firms were able to obtain improvements in the quality of product technologies from the interaction between knowledge storage and transfer practices. Along this line, other previous empirical evidence also confirmed this positive effect of knowledge storage on firm innovation (Alegre et al. 2013; Lee et al. 2013; Andreeva and Kianto 2011; Chen et al. 2010; Donate and de Pablo 2015; Serrano-Bedia et al. 2018a).

Regarding FFs, as previously mentioned, the literature shows that they are usually characterized by adopting an internal-oriented approach, which reduces dependence on the external environment (Beneito 2003) and facilitates the development of an absorptive capacity for effectively acquiring and incorporating external knowledge from the firm (Cohen and Levinthal 1990). Consequently, these firms could be expected to have more capacity to collect and store knowledge. The scarce empirical evidence in the FF context shows that the increase in knowledge storage practices does not generate more innovation (Serrano-Bedia et al. 2018a). Consequently, we propose:

Hypothesis 2 (H2). Knowledge storage management practices contribute to improvements in family firms' innovation outcomes.

\subsubsection{Transfer}

Intrafirm knowledge sharing can help organizational members absorb new knowledge and make knowledge replication easier, both of which could lead to higher levels of innovation for firms (Alavi and Tiwana 2003). Along this line, previous empirical research has linked knowledge dissemination practices to different types of organizational results, including improving product development outcomes ( $\mathrm{Li}$ and Zhao 2006; Lin and Chen 2006; Lawson et al. 2009; Li et al. 2009), although in other cases (Donate and de Pablo 2015; Serrano-Bedia et al. 2018a), no significant evidence of the relationship of knowledge transfer practices and innovation was found. Sharing knowledge is a central activity in most firms, but particularly in family-owned firms (Woodfield and Hust 2017). This is due to their tendency to maintain knowledge long-term within the family (Cabrera-Suárez et al. 2001; Miller et al. 2016) and the stable, personal, trust-based relationships among family and non-family actors (Arregle et al. 2007; Carnes and Ireland 2013), which make knowledge transfer easier than in other organizations (Jaskiewicz et al. 2013). Other advantages of family firms to facilitate knowledge sharing include connectedness and cohesion (Björnberg and Nicholson 2007), facilitating close ties among the members of the firm, which complements significantly the transfer of codified knowledge (Bojica et al. 2017), and the ability to build tacit knowledge between generations (Jaskiewicz et al. 2013). The result is a firm's increasing ability to identify new ways to recombine and extend its existing capabilities, thus supporting innovation (Carnes and Ireland 2013; Sirmon et al. 2011). According to these arguments and considering the absence of empirical studies about the relationship between knowledge transfer practices and innovation in the FF context, we argued that the greater the availability of KM transfer practices, the better a firm's innovation performance. Thus, the third hypothesis is the following: 
Hypothesis 3 (H3). Knowledge transfer management practices contribute to improvements in family firms' innovation outcomes.

\subsubsection{Application}

Firms learn by exploiting the knowledge transferred within the organization by the workers involved in the firm's processes (Messeni Petruzzelli et al. 2010; Matsuo 2015). However, application of the new knowledge to tangible operations is a complex task that takes time (Barney 1991) and an understanding of this complexity (Gold et al. 2001; Kogut and Zander 1992). Only when knowledge is appropriately used among organizational members, giving them the ability to transform various kinds of knowledge into creative products or technologies (Zahra and George 2002), are firms in a better condition to obtain a sustainable competitive advantage (Grant 1996; Kazanjian et al. 2010; Chen and Huang 2007). Empirical evidence of the positive relationship between knowledge application practices and innovation was found in Donate and de Pablo (2015), whereas in other papers (Serrano-Bedia et al. 2018a), no significant effect among both variables was found.

Stability and long-term orientation are important dimensions of familiness (Pearson et al. 2008). Furthermore, firms with high levels of familiness are likely to have more experience, due to the long-term orientation and the involvement of several generations, and are likely to possess more tacit knowledge (Pearson et al. 2008; Sirmon and Hitt 2003). This tacit knowledge is important for leveraging knowledge. Considering these arguments and the absence of empirical studies about the relationship between knowledge application practices and innovation in the FF context, we expected that the greater the availability of KM application practices for integrating and applying organizational knowledge, the better a firm's innovation performance. Thus, the fourth hypothesis is the following:

Hypothesis 4 (H4). Knowledge application management practices contribute to improvements in family firms' innovation outcomes.

\subsection{EO's Dimensions as Moderating Variables in the KMP-Innovation Relationship}

EO has been traditionally understood as a firm's strategic orientation and mostly measured as a multidimensional construct: innovativeness, proactiveness, and risk taking (Miller 1983; Covin and Slevin 1989; Covin and Miller 2014), although other approaches have extended this view to five dimensions by including competitiveness, aggressiveness, and autonomy (Lumpkin and Dess 1996; 2001). EO represents how firms use knowledge-based resources to discover and exploit new opportunities (Wiklund and Shepherd 2003; Teng 2007). EO can push firms to build an entrepreneurial climate that, by means of inspiring organizational learning and facilitating frequent intrafirm social interactions (Chen and Huang 2007), can moderate the relationship between knowledge-based resources and performance (Wiklund and Shepherd 2003).

Following previous studies that have focused on the individual study of some EO dimensions (e.g., Hatak et al. 2016; Madanoglu et al. 2016; Calabro et al. 2016; Vandekerkhof et al. 2015; Craig et al. 2014), in this paper, we explored the moderating influence of risk taking and proactiveness on the KMP-innovation outcomes relationship. Risk taking refers to the willingness to invest and commit resources with uncertain results, while proactiveness reflects an attitude toward the continuous pursuit of new opportunities (Pittino et al. 2018).

In family firms, the development of a sense of stewardship toward the organization (e.g., Corbetta and Salvato 2004; Hernandez 2012) can be viewed as a source of proactive exploration of new innovative opportunities (Pittino et al. 2018). Proactiveness creates the perception of a common purpose that stimulates family members' engagement in value-creating activities (e.g., Chirico 2008; Eddleston et al. 2010). This entrepreneurial climate can strengthen the internal knowledge sharing (Barroso-Martínez et al. 2016) previously accumulated in repositories through storage practices, for creative thoughts (Norrgren and Schaller 1999), and thus help firms find new opportunities to more effectively engage in knowledge application, and further benefit the firm's innovation ( $\mathrm{Li}$ et al. 2006). 
Regarding the risk-taking EO dimension, innovation is a highly risky, resource-consuming, lengthy, and uncertain process that involves the application of technologies to market opportunities (Tushman and Nadler 1986) through sharing knowledge with the firms (Li and Atuahene-Gima 2001; Subramaniam and Youndt 2005). FFs are usually associated with a conservative and risk-averse posture (Huybrechts et al. 2013), reinforcing their trend to pursue exploitative innovation strategies with a focus on incremental innovations (Fuetsch and Suess-Reyes 2017). Moreover, strong empirical evidence shows that FFs invest less in innovation, but have an increased conversion rate of innovation input into output and, ultimately, a higher innovation output than non-FFs (De Massis et al. 2013; Duran et al. 2016; Roed 2016; Fuetsch and Suess-Reyes 2017). Considering this particular innovative behavior of family firms, we argue that the existence of a greater propensity to take risks in these firms may favor a willingness to invest and commit resources in knowledge creation and exploitation, thus leveraging innovation performance.

Studies that have explored the role of EO as a moderating variable on the KMP-innovation relationship are, to the best of our knowledge, absent in the literature (Serrano-Bedia et al. 2018b). Therefore, considering the previous arguments, we hypothesize:

Hypothesis 5a (H5a). In FFs, proactiveness positively moderates the relationship between KMP and innovation outcomes, such that the effect of KMP on innovation outcomes is stronger in FFs with high proactiveness that in firms with low proactiveness.

Hypothesis $\mathbf{5 b} \mathbf{( H 5 b )}$. In FFs, risk taking positively moderates the relationship between KMP and innovation outcomes, such that the effect of KMP on innovation outcomes is stronger in high risk-taking FFs than in more risk-averse firms.

\section{Materials and Methods}

\subsection{Data Source}

The sample of our study was 288 family firms. A questionnaire was developed after an extensive literature review, exploring a wide range of issues relating to family characteristics, KMP, and innovation. CEOs were used as key informants (Kumar et al. 1993), since they receive information from a wide range of departments, and therefore are a very valuable source for evaluating the different variables of the organization.

\subsection{Measurement and Variables}

The scales used for the construction of the multi-item variables were subjected to validity and reliability by using principal component analysis and by calculating the Cronbach's alpha for each scale. The results support the validity of these scales, as indicated by the amount of variance explained and the loading factors of all the items within each scale-surpassing the threshold point of 0.5 (Hair et al. 1998)—and the Cronbach's alpha for the scales—surpassing the threshold point of 0.7 (Nunnally 1978).

Dependent variables: The measurement of innovation was based on four different types of innovation outcomes: product, process, organizational, and commercial innovation, which is in line with the Oslo Manual's definition of innovation (Manual 2005).

Product innovation was constructed based upon the following four items, whose importance was rated by firms on a five-point scale (Cronbach's alpha $=0.885$ ):

- During the period 2015-2017, the firm introduced products new to the market, or services incrementally improved.

- During the period 2015-2017, the firm introduced products new to the market, or services radically improved. 
- During the period 2015-2017, the firm introduced products, or services incrementally improved in existing markets.

- During the period 2015-2017, the firm introduced products, or services radically improved in existing markets.

For measuring process innovation, firms were asked to rate the importance on a five-point scale if 'during the period 2015-2017 they have introduced new methods of production, logistic systems, distribution methods, or support activities incrementally or radically improved'.

For measuring organizational innovation, firms were asked to rate the importance on a five-point scale if 'during the period 2015-2017 they have introduced new business practices in the organization of the work, the procedures of the company, and/or new methods of management of relations with companies/institutions'.

For measuring commercial innovation, firms were asked to rate the importance on a five-point scale if 'during the period 2015-2017, they have introduced new commercial strategies that differ significantly from the previous ones and have not been previously used'.

Independent variables: We adopted the items of Donate and de Pablo (2015) regarding four knowledge management practices (creation, storage, transfer, and application). Firms were asked to rate the importance of these items related to the four types of knowledge management practices on a five-point scale.

Creation was measured using the following four items (Cronbach's alpha $=0.831$ ):

- There is a strong commitment to depend on internal $R \& D$ activities to develop or improve technologies.

- There is a strong investment in R\&D activities to develop or improve technologies internally.

- There is a strong commitment to use proprietary technology to develop or improve product/process.

- There is a strong commitment to maintain a highly qualified R\&D unit to internally develop or improve technologies.

The construction of storage was based upon the following seven items (Cronbach's alpha $=0.789$ ):

- Organizational processes are codified and documented in manuals or other types of devices.

- There are databases that allow employees to use knowledge and experiences that have previously been loaded into the databases.

- $\quad$ There are phone or e-mail directories to find experts in specific areas.

- It is possible to access knowledge repositories, databases, and documents through some kind of internal computer network.

- There are databases with updated information about customers.

- Databases are frequently updated.

- There are procedural guidelines, manuals, or books including problems that have been solved successfully.

Transfer was based upon the following eight items (Cronbach's alpha $=0.854)$ :

- Information technologies (internet, intranet, e-mail, etc.) are used in order to encourage information flows and improve employees' communication.

- The firm's objectives and goals are clearly communicated to all the organizational members.

- There are frequent, well-distributed internal reports that inform employees about the firm's progress.

- There are periodical meetings in which employees are informed about the new initiatives that have been implemented.

- There are formal mechanisms that guarantee the best practices to be shared in the firm.

- There are projects with interdisciplinary teams to share knowledge. 
- There are employees that compile suggestions from other employees, customers, and suppliers, and produce structured reports to distribute throughout the company.

- There are communities of practices or learning groups to share knowledge and experiences.

Finally, application was constructed by adopting the following five items (Cronbach's alpha $=0.721)$ :

- All the employees have access to relevant information and key knowledge within the firm.

- There are interdisciplinary teams with autonomy to apply and integrate knowledge.

- Suggestions from employees, customers, or suppliers are frequently incorporated into products, processes, or services.

- Knowledge that has been created is structured in independent modules, which allow for its integration or separation to create different applications and new usages.

- It is quite common to use external experts with experience on a specific subject in order to solve particular problems.

Moderator variables: In order to test how the entrepreneurial oriental of a firm can moderate the relationship between knowledge management practices and innovation, two moderator variables were measured: proactiveness and risk taking. The measurement of these variables was based on the items adopted from Saha et al. (2017). Firms were asked to rate the importance of these items related to different types of knowledge management practices on a five-point scale.

Proactiveness was measured using the following three items (Cronbach's alpha $=0.786$ ):

- We seek to exploit anticipated changes in future market conditions ahead of our rivals.

- We look forward to seizing initiatives whenever possible in our target market operations.

- We act opportunistically to shape the business environment in which we operate.

For measuring risk taking, the following three items were adopted (Cronbach's alpha $=0.836$ ):

- Our business, in general, tends to invest in high-risk projects.

- Our business shows a great deal of tolerance for venturing into the unknown.

- Our business strategy is characterized by a tendency to commit resources into projects with uncertain outcomes.

Additionally, in the analysis, we included a set of control variables with the aim of avoiding biased results for not including them. These variables were selected based on previous literature about knowledge management practices, innovation, and family business research. These variables were size, manufacturers, services, CEO tenure, family involvement, cooperation with universities, and cooperation with other institutions.

First, we controlled for firm size using the logarithm of the number of employees. Second, we included two dummy variables controlling for the sector activity of the firms. Considering the three category groups of sectors (manufacturers, services, and construction), we included two controls (manufacturers and services), taking construction as a reference category. Thirdly, we also controlled for the specific family characteristics of the firms. On the one hand, we included the CEO tenure variable, which was measured as the number of years the CEO had worked in the firm. On the other hand, family involvement measured the number of family members working in the firm. Finally, two dummy variables measuring activities of cooperation in R\&D with universities (Coop University) or other institutions (Coop Others) were also included in the model.

\subsection{Methodology}

In order to estimate the effect of different KMPs on innovation, as well as the moderator effect of risk taking and proactiveness on this relationship, this empirical study was based on a linear regression by ordinary least squares (OLS) over the dependent variable. 
Table 1. Correlation matrix and variance inflation factors (VIFs).

\begin{tabular}{|c|c|c|c|c|c|c|c|c|c|c|c|c|c|}
\hline & V1 & V2 & V3 & $\mathrm{V} 4$ & V5 & V6 & V7 & V8 & V9 & V10 & V11 & V12 & VIF \\
\hline V1: Size & & & & & & & & & & & & & 1.126 \\
\hline V2: Manufacturers & 0.016 & & & & & & & & & & & & 2.856 \\
\hline V3: Services & 0.001 & $-0.764^{* * *}$ & & & & & & & & & & & 2.903 \\
\hline V4: CEO Tenure & -0.088 & 0.112 & -0.043 & & & & & & & & & & 1.112 \\
\hline V5: Fam Involvement & $0.181^{* * *}$ & 0.045 & -0.060 & 0.026 & & & & & & & & & 1.063 \\
\hline V6: Coop University & $0.193^{* * *}$ & -0.018 & 0.044 & -0.033 & -0.038 & & & & & & & & 1.231 \\
\hline V7: Coop Others & $0.156^{* * *}$ & 0.039 & 0.003 & -0.048 & -0.038 & $0.270^{* * *}$ & & & & & & & 1.117 \\
\hline V8: Creation & 0.092 & $0.149^{* *}$ & $-0.142^{* *}$ & 0.091 & 0.053 & $0.274^{* * *}$ & 0.093 & & & & & & 1.743 \\
\hline V9: Storage & 0.079 & 0.091 & -0.103 & -0.100 & 0.027 & $0.201^{* * *}$ & $0.188^{* * *}$ & $0.486^{* * *}$ & & & & & 1.962 \\
\hline V10: Transfer & 0.060 & 0.047 & 0.019 & -0.086 & 0.009 & $0.214^{* * *}$ & $0.188^{* * *}$ & $0.470^{* * *}$ & $0.632^{* * *}$ & & & & 3.100 \\
\hline V11: Application & 0.048 & 0.040 & -0.016 & -0.030 & 0.063 & $0.240^{* * *}$ & $0.177^{* * *}$ & $0.416^{* * *}$ & $0.584^{* * *}$ & $0.798^{* * *}$ & & & 2.887 \\
\hline V12: Risk Taking & 0.009 & 0.085 & -0.081 & -0.124 & 0.034 & $0.121 * * *$ & 0.075 & $0.402 * * *$ & $0.260^{* * *}$ & $0.293 * * *$ & $0.347^{* * *}$ & & 1.393 \\
\hline V13: Proactiveness & 0.078 & 0.038 & 0.006 & -0.079 & 0.020 & $0.197^{* * *}$ & $0.156^{* * *}$ & $0.406^{* * *}$ & $0.416^{* * *}$ & $0.447^{* * *}$ & $0.480 * * *$ & $0.416^{* * *}$ & 1.617 \\
\hline
\end{tabular}

${ }^{*} p<0.05,{ }^{* *} p<0.01,{ }^{* * *} p<0.001$. Source: Own elaboration. 
The correlations and variance inflation factors (VIFs) are shown in Table 1. We only observed moderate levels of correlations (all smaller than 0.584) between our variables, under the recommended threshold of 0.65 (Tabachnick and Fidell 2012). Multicollinearity was analyzed by using the variance inflation factor together with the condition indexes. The resulting variance inflation factors (all smaller than 3.100) and highest condition index (17.19) suggested that multicollinearity was not a concern in this study.

\section{Results}

The regression results are summarized in Table 2. As far as the effect of the control variables, four of them (manufacturers, services, cooperation with universities, and cooperation with other institutions) had a significant effect on different innovation outcomes. Beginning with sector controls, both Manufacturers and Services positively impacted product innovation. Following with Cooperation with universities, the results suggest that these kinds of networks fostered the development of both product and commercial innovations. Finally, regarding Cooperation with other institutions, we found that it only had a positive and significant effect in the case of organizational innovations.

Table 2. Ordinary least squares regression results. EO: entrepreneurial orientation, KMP: knowledge management practices.

\begin{tabular}{|c|c|c|c|c|}
\hline & Innoprod & Innoproc & Innorg & Innocom \\
\hline \multicolumn{5}{|l|}{ Control } \\
\hline Size & $0.019(0.084)$ & $0.125(0.130)$ & $0.165(0.118)$ & $0.110(0.126)$ \\
\hline Manufacturers & $0.325(0.197)$ * & $0.063(0.304)$ & $-0.077(0.275)$ & $-0.087(0.295)$ \\
\hline Services & $0.298(0.182) *$ & $0.174(0.281)$ & $-0.179(0.254)$ & $-0.066(0.272)$ \\
\hline CEO Tenure & $0.001(0.005)$ & $-0.003(0.008)$ & $-0.002(0.007)$ & $-0.005(0.007)$ \\
\hline Fam Involvement & $0.032(0.023)$ & $0.029(0.036)$ & $-0.018(0.032)$ & $0.024(0.034)$ \\
\hline Coop University & $0.350(0.120)^{* * *}$ & $0.078(0.185)$ & $0.210(0.167)$ & $0.336(0.179) *$ \\
\hline Coop Others & $-0.26(0.118)$ & $0.150(0.182)$ & $0.314(0.164)^{* *}$ & $0.053(0.176)$ \\
\hline \multicolumn{5}{|l|}{ KMP } \\
\hline Creation & $-0.002(0.066)$ & $0.155(0.102) *$ & $0.147(0.092) *$ & $0.191(0.099)^{* *}$ \\
\hline Storage & $0.165(0.070)^{* *}$ & $0.110(0.109)$ & $-0.008(0.098)$ & $-0.014(0.105)$ \\
\hline Transfer & $0.047(0.074)$ & $0.013(0.114)$ & $0.177(0.103)^{*}$ & $0.050(0.110)$ \\
\hline Application & $0.086(0.095)$ & $0.186(0.14)$ & $0.276(0.133) * *$ & $0.158(0.142)$ \\
\hline \multicolumn{5}{|l|}{ Moderators EO } \\
\hline Risk Taking & $-0.037(0.090)$ & $-0.034(0.138)$ & $-0.117(0.125)$ & $0.025(0.134)$ \\
\hline Proactiveness & $0.445(0.067)^{* * *}$ & $0.403(0.103)^{* * *}$ & $0.329(0.093)^{* * *}$ & $0.318(0.100)^{* * *}$ \\
\hline \multicolumn{5}{|l|}{ Interactive terms } \\
\hline Creation $x$ Risk Taking & $0.020(0.066)$ & $0.010(0.102)$ & $-0.085(0.092)$ & $-0.155(0.099) *$ \\
\hline Creation $x$ Proactiveness & $-0.171(0.065) * * *$ & $-0.142(0.101)^{*}$ & $-0.109(0.091)$ & $-0.048(0.097)$ \\
\hline Storage $\mathrm{x}$ Risk Taking & $0.145(0.084) *$ & $-0.031(0.130)$ & $0.084(0.118)$ & $0.114(0.126)$ \\
\hline Storage $x$ Proactiveness & $-0.026(0.075)$ & $0.052(0.116)$ & $0.048(0.105)$ & $0.002(0.112)$ \\
\hline Transfer $x$ Risk Taking & $-0.265(0.105) * *$ & $-0.115(0.163)$ & $0.068(0.147)$ & $0.017(0.158)$ \\
\hline Transfer $\mathrm{x}$ Proactiveness & $0.067(0.092)$ & $-0.075(0.143)$ & $-0.063(0.129)$ & $-0.1469(0.138)$ \\
\hline Application $\mathrm{x}$ Risk Taking & $0.067(0.095)$ & $-0.116(0.147)$ & $-0.225(0.133)^{*}$ & $-0.065(0.143)$ \\
\hline Application $x$ Proactiveness & $0.028(0.093)$ & $0.285(0.143)^{* *}$ & $0.150(0.129)$ & $0.150(0.139)$ \\
\hline Constant & $-0.469(0.308)$ & $2.173(0.475)^{* * *}$ & $2.481(0.429)^{* * *}$ & $2.570(0.460)^{* * *}$ \\
\hline $\mathrm{R}$ & 0.662 & 0.516 & 0.568 & 0.503 \\
\hline $\mathrm{R}^{2}$ & 0.439 & 0.266 & 0.323 & 0.253 \\
\hline Adjusted $\mathrm{R}^{2}$ & 0.386 & 0.197 & 0.259 & 0.183 \\
\hline $\mathrm{F}$ & $8.304^{* * *}$ & $3.850^{* * *}$ & $5.059^{* * *}$ & $3.603^{* * *}$ \\
\hline
\end{tabular}

${ }^{*} p<0.05,{ }^{* *} p<0.01,{ }^{* * *} p<0.001$. Standard errors in brackets. Source: Own elaboration.

Regarding the effect of the knowledge management practices on innovation, the results were mixed depending on the type of KMP and the innovation outcome variable considered. On the one 
hand, creation positively and significantly impacted three types of innovation outcomes (process, organizational, and commercial), thus confirming H1. On the other hand, storage, transfer, and application only had positive and significant effects on product (storage) and organizational innovations (transfer and application). These results partially confirm H2, H3, and H4.

Regarding the direct effect of the two dimensions of entrepreneurial orientation studied, only proactiveness had a significant and positive effect on all the innovation types.

Finally, the moderating effect of proactiveness and risk taking on the relationship between KMPs and innovation was studied. Beginning with proactiveness, the results show significant interactions for the case of knowledge creation practice and product innovation, as well as for knowledge creation and application practices and process innovation, thus partially confirming H5a. To facilitate the interpretation of the moderation effects, these significant interactions are plotted in Figures 1-3.

Hypothesis 5a proposed that knowledge management practices and firms' proactiveness interact to positively influence firms' innovation outcomes. As Figure 1 shows, higher levels of knowledge creation reduced product innovation in the presence of high proactiveness, whereas knowledge creation increased product innovation when proactiveness was low. A gradient test revealed that the negative slope between knowledge creation and product innovation was non-significant when proactiveness was high $(t=-1.649, n . s$.$) , whereas the positive slope for low proactiveness was significant (t=2.020$, $p=0.044)$, thus not providing support for H5a.

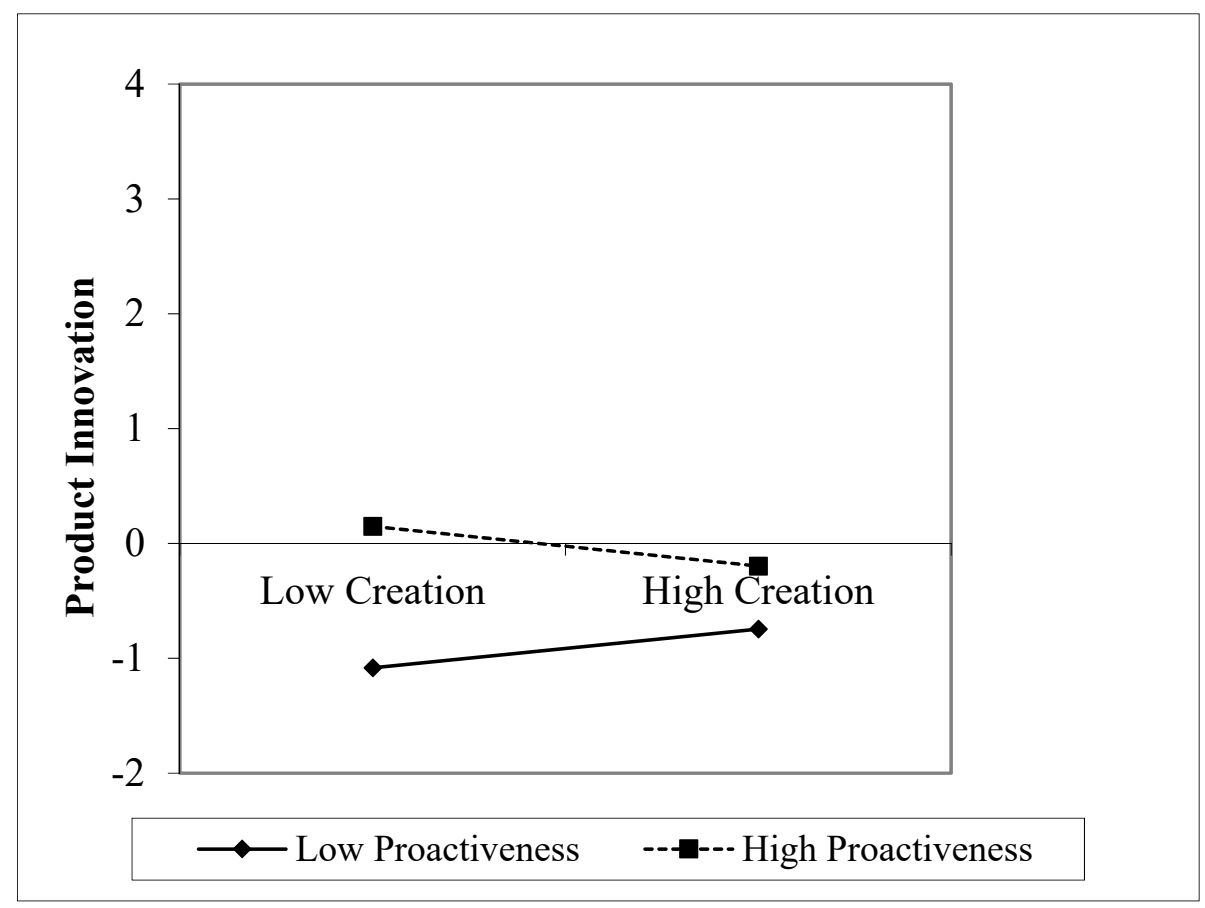

Figure 1. The moderating effect of proactiveness on the knowledge creation-product innovation relationship. Source: Own elaboration.

Regarding Figure 2, the positive association between knowledge creation and process innovation remained practically unchanged in the presence of high levels of proactiveness, whereas it was stronger when proactiveness was low. The gradient tests show that the slope between knowledge creation and process innovation was non-significant when proactiveness was high $(t=0.081, n . s$.$) , whereas the$ positive slope for low proactiveness was significant $(t=2.214, p=0.028)$, which are findings that do not support H5a. 


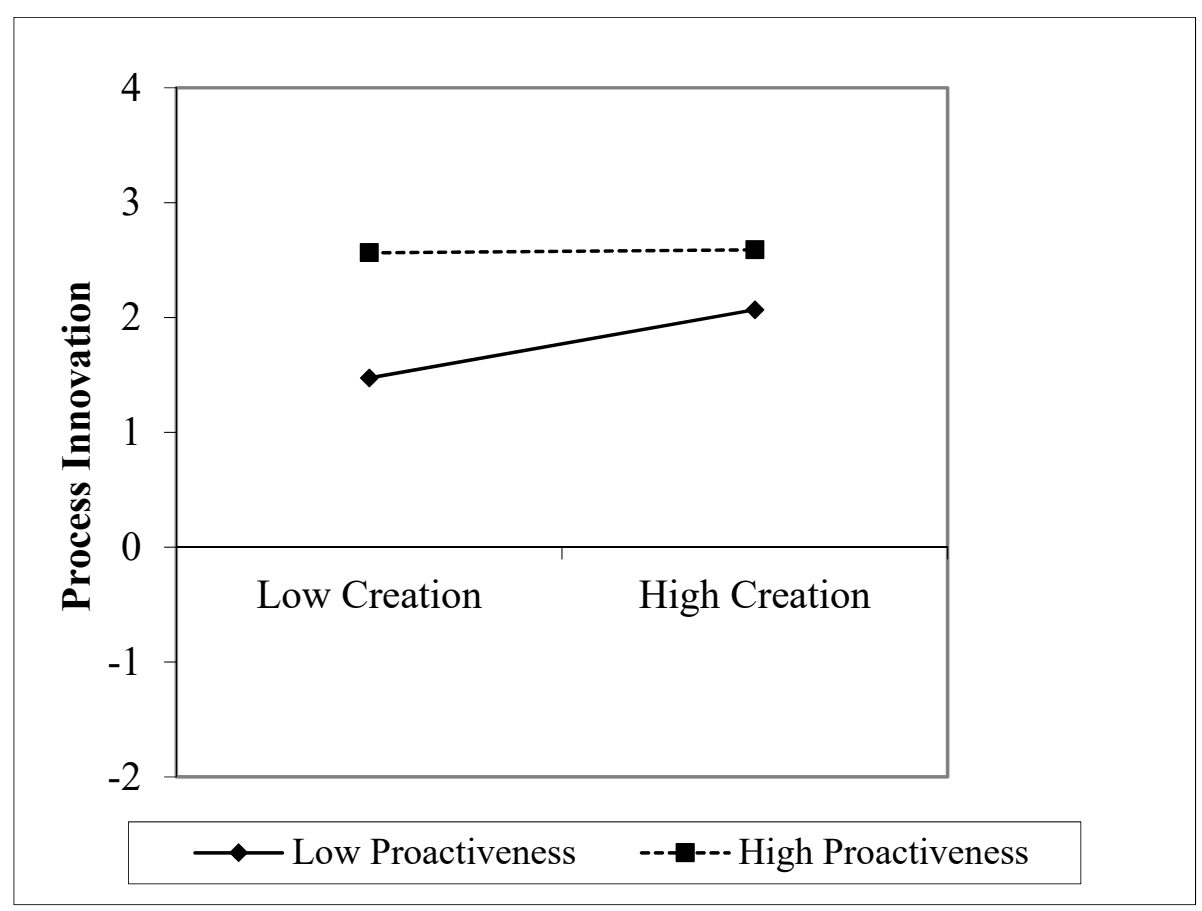

Figure 2. The moderating effect of proactiveness on the knowledge creation-process innovation relationship. Source: Own elaboration.

Finally, Figure 3 shows that the positive association between knowledge application and process innovation increased in the presence of high levels of proactiveness, whereas when proactiveness was low, higher levels of knowledge application diminished process innovation. A gradient test revealed that the positive slope between knowledge application and process innovation was significant $(t=3.612$, $p=0.000$ ) when proactiveness was high, whereas the slope for low proactiveness was non-significant $(t=-0.683$, n.s. $)$. These results provide support for H5a.

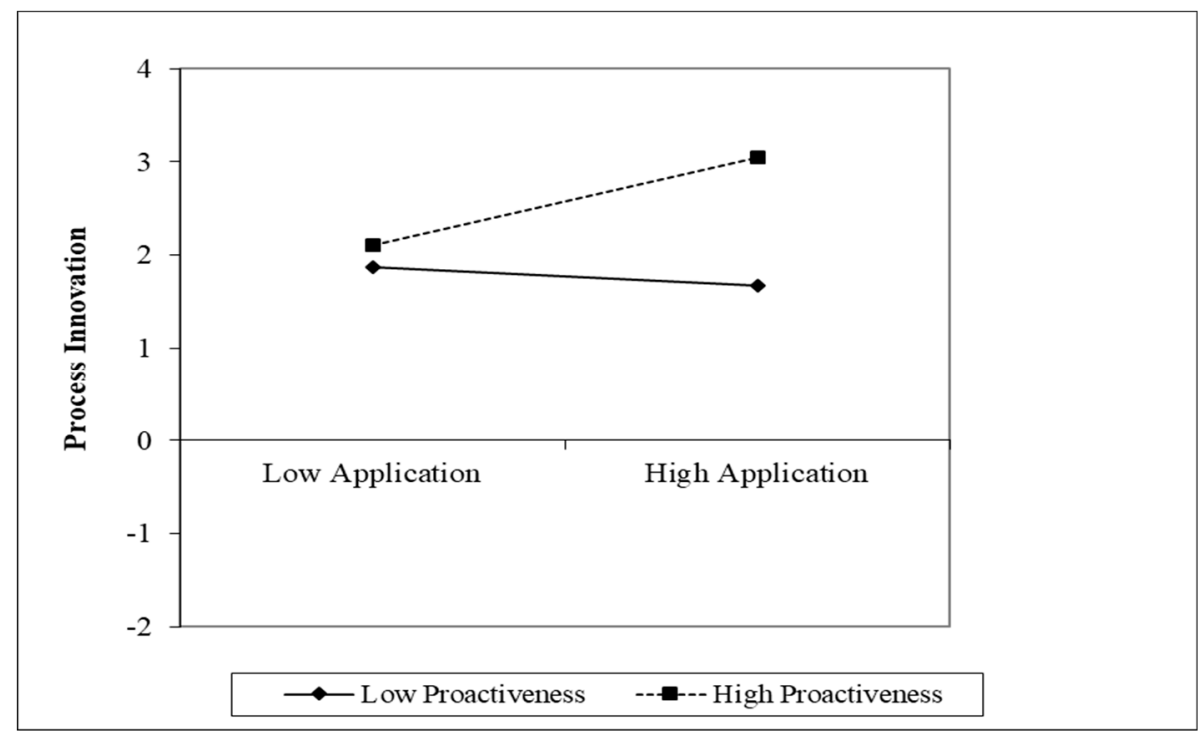

Figure 3. The moderating effect of proactiveness on the knowledge application-process innovation relationship. Source: Own elaboration.

Concerning risk taking, it moderated the relationship between (a) knowledge storage and transfer practices and product innovation, (b) knowledge creation and commercial innovation, and (c) 
knowledge application and organizational innovation, thus partially supporting H5b. To facilitate the interpretation of the moderation effects identified, these significant interactions are plotted in Figures $4-7$.

Hypothesis $5 \mathrm{~b}$ proposed that knowledge management practices and firms' risk taking would interact to positively influence firms' innovation outcomes. As Figure 4 shows, knowledge storage increased product innovation when risk taking was high, whereas the effect between both variables remained practically unchanged when risk taking was low. According to the gradient tests carried out, the slope between knowledge storage and product innovation was significant when risk taking was high $(t=3.705, p=0.000)$, whereas the slope for low risk taking was non-significant $(t=0.239$, n.s.). These results reveal that a firm's risk-taking attitude positively moderates the effect of knowledge storage on product innovation, thus providing support for $\mathrm{H} 5 \mathrm{~b}$.

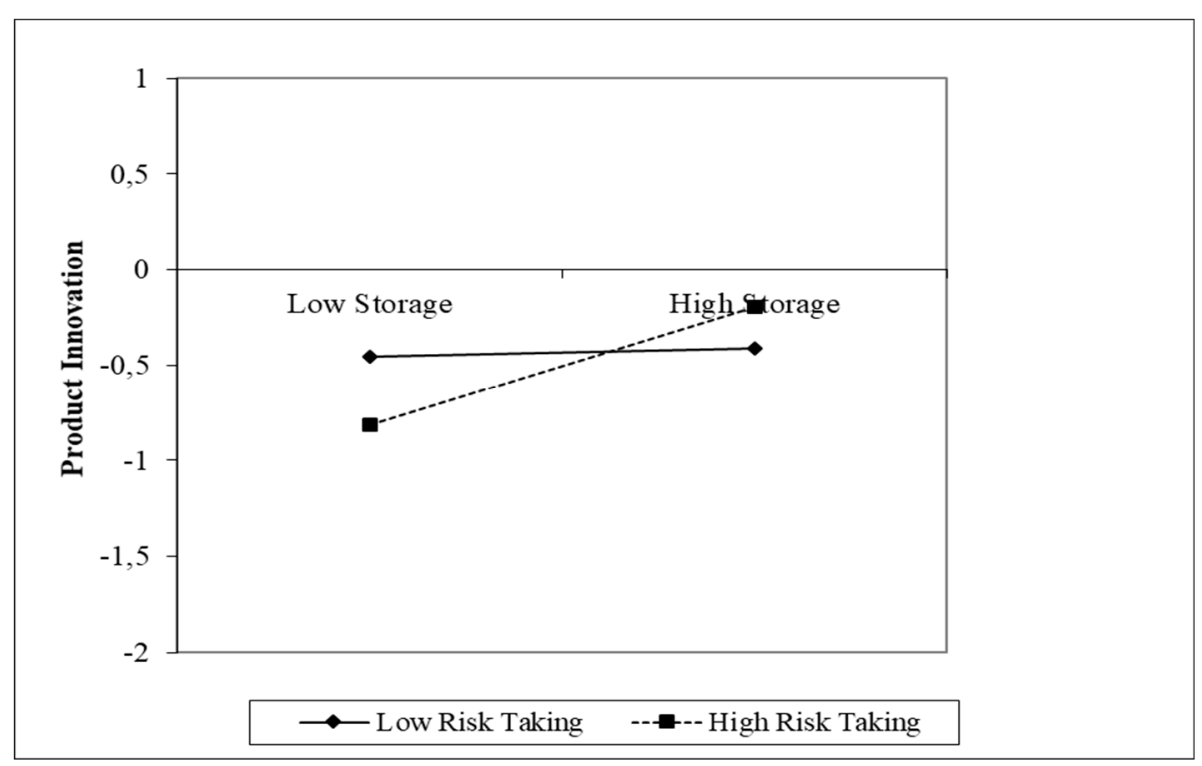

Figure 4. The moderating effect of risk-taking on the knowledge storage-product innovation relationship. Source: Own elaboration.

Moreover, Figure 5 shows that when risk taking was low, higher levels of knowledge transfer increased product innovation, whereas the opposite effect was found when risk taking was high. A gradient test revealed that the slope between knowledge transfer and product innovation was non-significant when risk taking was high $(\mathrm{t}=-1.407$, n.s.), whereas the slope for low risk taking was significant $(t=2.467, p=0.014)$. These results reveal that a firm's risk-taking attitude negatively moderates the effect of knowledge transfer on product innovation, thus not providing support for H5b.

Figure 6 shows the positive association between knowledge creation and commercial innovation increases in the presence of both low and high risk-taking levels, and this effect was stronger in the presence of low risk-taking levels. A gradient test revealed that the slope between knowledge creation and commercial innovation was non-significant when risk taking was high $(t=0.232$, n.s.), whereas the slope for low risk-taking was significant $(t=2.735, p=0.007)$. These results reveal that a firm's risk-taking attitude negatively moderates the effect of knowledge creation on commercial innovation, thus not providing support for $\mathrm{H} 5 \mathrm{~b}$.

The same effect previously explained was found for the relationship between knowledge application and organizational innovation when the moderating effect of risk taking was introduced, as can be seen in Figure 7. In this case, the findings (gradient test: $(t=0.269$, n.s.) for the slope between knowledge application and organizational innovation when risk taking was high, $(\mathrm{t}=2.801, p=0.005)$ when risk taking is low) reveal that a firm's risk-taking attitude negatively moderates the effect of knowledge application on organizational innovation, thus not providing support for H5b. 
The main results of the study can be summarized as follows:

- A positive and significant effect of knowledge creation on all the innovation measured, with the exception of product innovation, was found.

- Storage practices fostered innovation only for the case of product innovation.

- Both knowledge transfer and knowledge application encouraged organizational innovations.

- Proactiveness negatively moderated the effect of knowledge creation on both product and process innovation.

- Risk taking positively moderated the effect of knowledge storage on product innovation, while a negative moderator effect was found in the relationship between knowledge creation, transfer and application practices, and commercial, product, and organizational innovations.

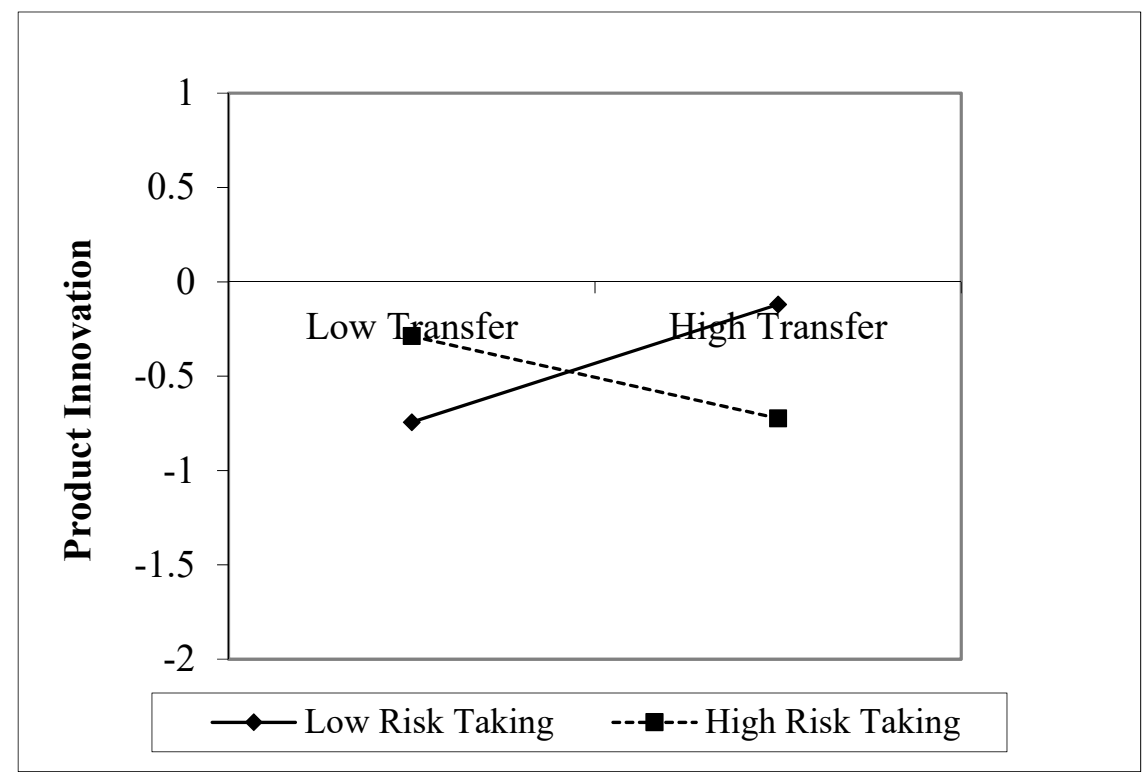

Figure 5. The moderating effect of risk-taking on the knowledge transfer-product innovation relationship. Source: Own elaboration.

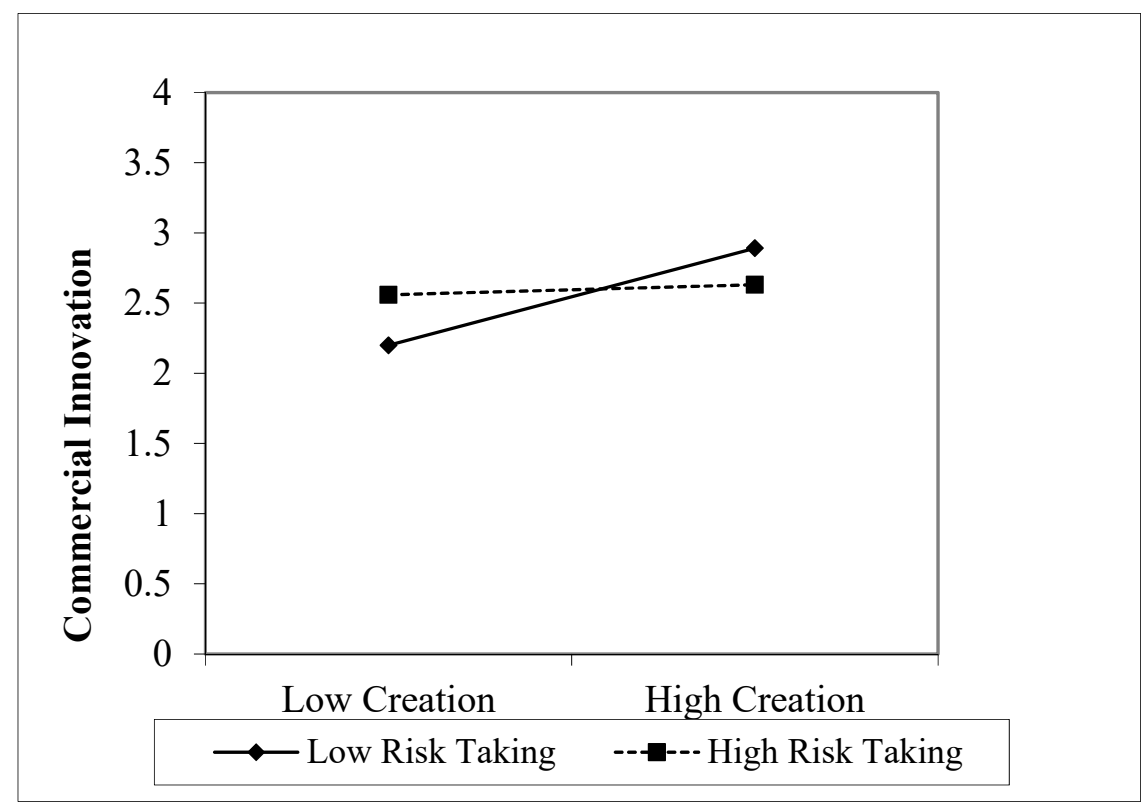

Figure 6. The moderating effect of risk-taking on the knowledge creation-commercial innovation relationship. Source: Own elaboration. 


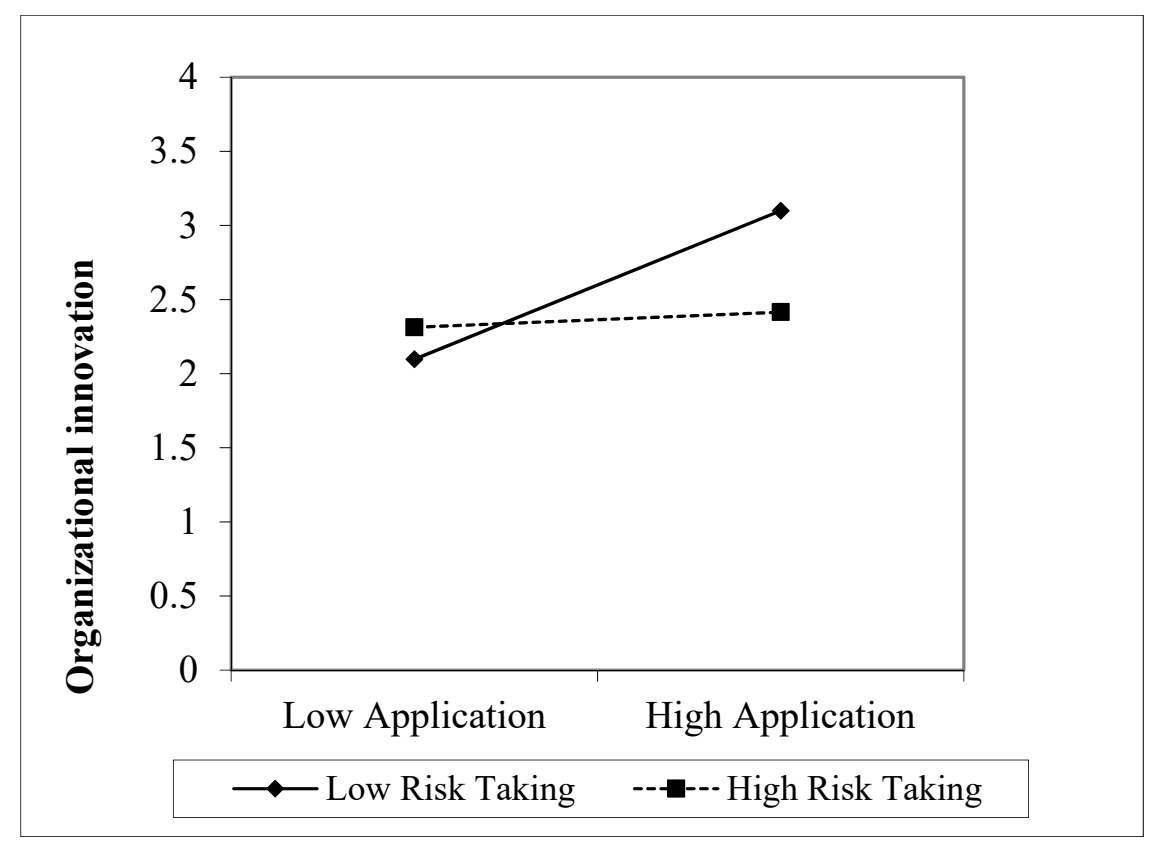

Figure 7. The moderating effect of risk-taking on the knowledge application-organizational innovation relationship. Source: Own elaboration.

\section{Implications}

The results of this study, confirming that only some KMPs had positive effects on innovation outcomes, offer interesting implications for both academics and decision-makers. In more concrete terms, enterprises interested in innovation activity should focus their efforts on knowledge creation, as it demonstrated a positive and significant effect on all the innovation measures, with the exception of product innovation. This result confirms the arguments that suggested that the development of new resources and capabilities allows firms to internally obtain and maintain positive returns on their innovation activities over time (Katila 2002; Katila and Ahuja 2002; Roberts and Amit 2003). As far as family firms, these results are also in line with previous evidence (Serrano-Bedia et al. 2016) and theoretical arguments suggesting that involvement in management and strategy facilitates the development of knowledge creation practices that generate innovation outcomes (De Clercq et al. 2013).

However, if firms are interested in the development of product innovation, they should be focused on storage KMP. In this case, the results confirm, only for the case of product innovation, that storage practices enabled firms to get better innovation results as they allow firms to improve the quality of the knowledge stored and its application and transfer (Argote and Ingram 2000; Purvis et al. 2001; Donate and de Pablo 2015). Along this line, although traditionally, research has demonstrated that KMPs have associations with innovation advantages in products (e.g., Chen and Huang 2007), as new or existing combined knowledge can contribute to either radical or incremental product innovation (Darroch and McNaughton 2002), this is only the case for storage management practices. Regarding family firms, this finding is contrary to the scarce available empirical evidence suggesting that in family firms, an increase in knowledge storage practices did not generate more innovation (Serrano-Bedia et al. 2018a), as well as contrary to previous arguments about their lower capacity to store knowledge and then to foster innovation based on this KMP (Andersén 2015).

Finally, knowledge transfer, facilitating knowledge sharing (Alavi and Tiwana 2003), and knowledge application encouraged organizational innovations, as previous literature suggested. Regarding family firms, this result seems to confirm that their tendency to maintain, share, and transfer knowledge due to their particular characteristics could be a key resource in supporting innovation (Carnes and Ireland 2013; Miller et al. 2016; Sirmon et al. 2011). Furthermore, as family firms are likely to possess more tacit knowledge, they will need to take advantage of it to innovate. However, 
the results related to the other possible combinations of KMP and innovation outcomes analyzed contradicted previous studies, showing that these practices did not influence innovation. These results are coherent with the lower level of R\&D investment among the FFs reported in previous studies.

Regarding proactiveness as a moderator of the relationship between KMP and innovation, the evidence found was mixed, and was only confirmed for product and process innovation and knowledge creation. Regarding process innovation, the results are in line with previous statements by Corbetta and Salvato (2004) or Pittino et al. (2018), among others, suggesting that the development of a sense of stewardship toward the organization within FFs makes them more proactive to exploit new innovative opportunities. However, this proactive attitude of FFs negatively moderated the effect of knowledge creation on both product and process innovation. A possible explanation for this result could be that in FFs, a more proactive attitude to generate in-house knowledge and maintain this knowledge within the family makes them more focused on areas closely related to pre-existing knowledge and less open to new external knowledge, which, in turn, could negatively influence technological innovation (Mascarenhas 1985).

Finally, concerning the moderating effect of risk taking, the evidence found was mixed and confirmed for some KMPs and all the innovation measures, with the exception of process innovation. More precisely, risk taking positively moderated the effect of knowledge storage on product innovation, while a negative moderator effect was found in the relationship between knowledge creation, transfer and application practices, and commercial, product, and organizational innovations, respectively. The positive moderating effect found suggests that when FFs assume high risks oriented to improve the quality of technologies used to store knowledge, they are in a better position to make a better use of their internal codified knowledge base, thus facilitating the development of product innovation. The negative moderator results can be justified because the existence of a greater propensity to take risks, investing and committing resources in the innovation process, is contrary to the conservative and risk-averse posture usually associated to FFs in the literature (e.g., Huybrechts et al. 2013). For this reason, we suspect that only in the presence of more explorative innovation strategies with a focus on radical innovations can risk taking in FFs lead to better innovation outcomes, which is an argument that should be deeply explored in further studies.

These findings also have valuable managerial implications. This is because by contributing to a better understanding of the most effective KMP practices that are likely to have an effect on different innovation outcomes, they serve as a guideline for managers aiming to reinforce innovative behavior and results. Along this line, firms should be focused on specific KMPs, depending on the innovation type to be developed. This provides an interesting picture in order to design a more appropriate KMP strategy for fostering firms' innovative capacities. On the other hand, our results show that managers should pay attention to the development of the competences that allow them to strengthen the relationship between KMP and EO, as well as between KMP and innovation.

\section{Conclusions}

This paper aimed to study the relationships between KMP and innovation outcomes (product, process, organizational, and commercial) and how they can be moderated by two dimensions of the EO (proactiveness and risk taking) in a sample of 288 SME Spanish family firms. In doing so, this study made at least three contributions to the literature. First, it contributes to previous literature by deepening the study of the relationships between two key constructs in management literature-KMP and innovation - by considering a broad range of KMPs and innovation outcomes. Secondly, we added to the limited research on KM in the FF context. Thirdly, the work was pioneering in researching the moderating influence of two EO dimensions on the KMP-innovation outcomes relationship. In line with previous evidence, the results confirm the positive effect of all the KMPs studied for at least one of the innovation types studied for the case of Spanish family firms. Furthermore, the introduction of different innovation outcome types in the analysis demonstrates how these effects can vary depending on the innovation type analyzed. Regarding the moderator effect of proactiveness and risk taking, it was also dependent on the KMP and innovation outcome pursued by firms. 
Despite the contributions of this study to family business, knowledge management, and entrepreneurship literatures, it is also important to acknowledge its limitations. First, this study was cross-sectional and used subjective measures. Although cross-sectional designs are common in strategic literature (e.g., Bojica et al. 2017; Klammer Adrian et al. 2017), they constrain the strength of the causal inferences that can be made. Hence, a longitudinal design might help elucidate the findings further. Secondly, this research was limited to one country under investigation (Spain), and although globalization seems to lead to similarities in business conduct across countries (e.g., Carr 2005), we recognize that organizations may be affected by national cultures (Hofstede 2001), and can offer different answers to the same problem depending on the cultural factors that surround them.

The results of this study would be enriched by extending our research to other countries and cultural contexts. Moreover, the generalizability of our findings was limited by the nature of the sample used in this study, and future studies will determine whether these results will hold for other samples.

Author Contributions: Conceptualization, A.-M.S.-B.; Formal analysis, G.G.-P.; Investigation, G.G.-P., A.-M.S.-B., and M.P.-P.; Methodology, G.G.-P.; Supervision, G.G.-P. and A.-M.S.-B.; Validation, G.G.-P.; Writing-original draft, G.G.-P., A.-M.S.-B. and M.P.-P.; Writing—review and editing, G.G.-P., A.-M.S.-B. and M.P.-P.

Funding: This research has received financial support from the 2016 Emerging Group Project of Vice President for Research and Knowledge Transfer at the University of Cantabria.

Conflicts of Interest: The authors declare no conflicts of interest with respect to the research, authorship, and/or publication of this article.

\section{References}

Alavi, Maryam, and Dorothy E. Leidner. 2001. Knowledge management and knowledge management systems: Conceptual foundations and research issues. MIS Quarterly 25: 107-36. [CrossRef]

Alavi, Maryam, and Amrit Tiwana. 2003. Knowledge management: The information technology dimension. In Organizational Learning and Knowledge Management. Edited by Mark Easterby-Smith and Marjorie A. Lyles. London: Blackwell Publishing, pp. 104-21.

Alegre, Joaquín, Kishore Sengupta, and Rafael Lapiedra. 2013. Knowledge management and innovation performance in a high-tech SMEs industry. International Small Business Journal 31: 454-70. [CrossRef]

Amabile, Teresa M., Regina Conti, Heather Coon, Jeffrey Lazenby, and Michael Herron. 1996. Assessing the work environment for creativity. Academy of Management Journal 39: 1154-84.

Andersén, Jim. 2015. The absorptive capacity of family firms: How familiness affects potential and realized absorptive capacity. Journal of Family Business Management 5: 73-89.

Andreeva, Tatiana, and Aino Kianto. 2011. Knowledge processes, knowledge-intensity and innovation: A moderated mediation analysis. Journal of Knowledge Management 15: 1016-34. [CrossRef]

Schiuma, Giovanni, Tatiana Andreeva, and Aino Kianto. 2012. Does knowledge management really matter? Linking knowledge management practices, competitiveness and economic performance. Journal of Knowledge Management 16: 617-36.

Argote, Linda, and Paul Ingram. 2000. Knowledge transfer: A basis for competitive advantage in firms. Organizational Behaviour and Human Decision Processes 82: 150-69. [CrossRef]

Argote, Linda, Bill McEvily, and Ray Reagans. 2003. Managing knowledge in organizations: An integrative framework and review of emerging themes. Management Science 49: 571-82. [CrossRef]

Arregle, Jean Luc, Michael A. Hitt, David G. Sirmon, and Philippe Very. 2007. The Development of Organizational Social Capital Attributes of Family Firms. Journal of Management Studies 44: 73-95. [CrossRef]

Barney, Jay. 1991. Firm resources and sustained competitive advantage. Journal of Management 17: 99-120. [CrossRef]

Barroso-Martínez, Ascensión, Ramón Sanguino Galván, and Tomás M. Bañegil Palacios. 2016. An empirical study about knowledge transfer, entrepreneurial orientation and performance in family firms. European Journal of International Management 10: 534-57.

Beneito, Pilar. 2003. Choosing among alternative technological strategies: An empirical analysis of formal sources of innovation. Research Policy 32: 693-713. [CrossRef]

Biscotti, Anna Maria, Eugenio D'Amico, and Filippo Monge. 2018. Do environmental management systems affect the knowledge management process? The impact on the learning evolution and the relevance of organisational context. Journal of Knowledge Management 22: 603-20. [CrossRef] 
Björnberg, Åsa, and Nigel Nicholson. 2007. The family climate scales—Development of a new measure for use in family business research. Family Business Review 20: 229-46. [CrossRef]

Bojica, Ana Maria, María del Mar Fuentes-Fuentes, and Virginia Fernández Pérez. 2017. Corporate entrepreneurship and codification of the knowledge acquired from strategic partners in SMEs. Journal of Small Business Management 55: 205-30. [CrossRef]

Branzei, Oana, and Ilan Vertinsky. 2006. Strategic pathways to product innovation capabilities in SMEs. Journal of Business Venturing 21: 75-105. [CrossRef]

Cabrera-Suárez, Katiuska, Petra De Saá-Pérez, and Desiderio García-Almeida. 2001. The succession process from a resource- and knowledge-based view of the family firm. Family Business Review 14: 37-48. [CrossRef]

Calabro, Andrea, Tommaso Minola, Giovanna Campopiano, and Thilo Justus Pukall. 2016. Turning innovativeness into domestic and international corporate venturing: The moderating effect of high family ownership and influence. European Journal of International Management 10: 505. [CrossRef]

Calvo-Mora, Arturo, Antonio Navarro-García, Manuel Rey-Moreno, and Rafael Periañez-Cristobal. 2016. Excellence management practices, knowledge management and key business results in large organisations and SMEs: A multi-group analysis. European Management Journal 34: 661-73. [CrossRef]

Carnes, Christina Matz, and R. Duane Ireland. 2013. Familiness and Innovation: Resource Bundling as the Missing Link. Entrepreneurship Theory and Practice 37: 1399-419. [CrossRef]

Carr, Chris. 2005. Are German, Japanese and Anglo-Saxon strategic decision styles still different in the context of globalization? Journal of Management Studies 42: 1155-88. [CrossRef]

Chen, Chung-Jen, and Jing-Wen Huang. 2007. How organizational climate and structure affect knowledge-The social interaction perspective. International Journal of Information Management 27: 104-18. [CrossRef]

Chen, Chung-Jen, Jing-Wen Huang, and Yung-Chang Hsiao. 2010. Knowledge management and innovativeness: The role of organizational climate and structure. International Journal of Manpower 31: 848-70. [CrossRef]

Chen, Hsiang-Lan, and Wen-Tsung Hsu. 2009. Family ownership, board independence, and R\&D investment. Family Business Review 22: 347-62.

Chirico, Francesco. 2008. Knowledge accumulation in family firms: Evidence from four cases studies. International Small Business Journal 26: 433-62. [CrossRef]

Chirico, Francesco, and Carlo Salvato. 2008. Knowledge integration and dynamic organizational adaptation in family firms. Family Business Review 21: 169-81. [CrossRef]

Chirico, Francesco, and Carlo Salvato. 2016. Knowledge internalization and product development in family firms: When relational and affective factors matter. Entrepreneurship Theory and Practice 40: 201-29. [CrossRef]

Cohen, Wesley M., and Daniel A. Levinthal. 1990. Absorptive capacity: A new perspective on learning and innovation. Administrative Science Quarterly 35: 128-52. [CrossRef]

Corbetta, Guido, and Carlo Salvato. 2004. Self-serving or self-actualizing? Models of man and agency costs in different types of family firms: A commentary on "Comparing the agency costs of family and non-family firms: Conceptual issues and exploratory evidence". Entrepreneurship Theory and Practice 28: 355-62. [CrossRef]

Covin, Jeffrey G., and Danny Miller. 2014. International Entrepreneurial Orientation: Conceptual Considerations, Research Themes, Measurement Issues, and Future Research Directions. Entrepreneurship Theory and Practice 38: 11-44. [CrossRef]

Covin, Jeffrey G., and Dennis P. Slevin. 1989. Strategic management of small firms in hostile and benign environments. Strategic Management Journal 10: 75-87. [CrossRef]

Craig, Justin B., Mikko Pohjola, Sascha Kraus, and Soren. H. Jensen. 2014. Exploring Relationships among Proactiveness, Risk-Taking and Innovation Output in Family and Non-Family Firms. Creativity and Innovation Management 23: 199-210. [CrossRef]

Cunningham, James, Claire Seaman, and David McGuire. 2016. Knowledge sharing in small family firms. Journal of Family Business Strategy 7: 34-46. [CrossRef]

Darroch, Jenny, and Rod McNaughton. 2002. Examining the link between knowledge management practices and types of innovation. Journal of Intellectual Capital 3: 210-22. [CrossRef]

De Clercq, Dirk, Dimo Dimov, and Narongsak Thongpapanl. 2013. Organizational social capital, formalization, and internal knowledge sharing in entrepreneurial orientation formation. Entrepreneurship Theory and Practice 37: 505-37. [CrossRef]

De Massis, Alfredo, Federico Frattini, and Ulrich Lichtenthaler. 2013. Research on Technological Innovation in Family Firms: Present Debates and Future Directions. Family Business Review 26: 10-31. [CrossRef] 
Del Giudice, Manlio, and Vincenzo Maggioni. 2014. Managerial practices and operative directions of knowledge management within inter-firm networks: A global view. Journal of Knowledge Management 18: 841-46. [CrossRef]

DiPasquale, Joanna, and Claire McInerney. 2010. Knowledge management in small-and medium-sized enterprises. Journal of Information and Knowledge Management 9: 341-53. [CrossRef]

Donate, Mario J., and Jesús D. Sánchez de Pablo. 2015. The role of knowledge-oriented leadership in knowledge management practices and innovation. Journal of Business Research 68: 360-70. [CrossRef]

Du Plessis, Marina. 2007. The role of knowledge management in innovation. Journal of Knowledge Management 11: 20-29. [CrossRef]

Duran, Patricio, Nadine Kammerlander, Marc van Essen, and Thomas Zellweger. 2016. Doing More with Less: Innovation Input and Output in Family Firms. Academy of Management Journal 59: 1224-64. [CrossRef]

Eddleston, Kimberly A., Franz W. Kellermanns, and Thomas M. Zellweger. 2010. Exploring the entrepreneurial behavior of family firms: Does the stewardship perspective explain differences? Entrepreneurship Theory and Practice 36: 347-67. [CrossRef]

Eisenhardt, Kathleen M., and Jeffrey A. Martin. 2000. Dynamic capabilities: What are they? Strategic Management Journal 21: 1105-21. [CrossRef]

Fang, Hanquing, Josip Kotlar, Esra Memili, James Chrisman, and Alfredo De Massis. 2018. The pursuit of international opportunities in family firms: Generational differences and the role of knowledge-based resources. Global Strategy Journal 8: 136-57. [CrossRef]

Fuetsch, Elena, and Julia Suess-Reyes. 2017. Research on innovation in family businesses: Are we building an ivory tower? Journal of Family Business Management 7: 44-92. [CrossRef]

Garud, Raghu, Philipp Tuertscher, and Andrew H. Van de Ven. 2013. Perspectives on Innovation Processes. The Academy of Management Annals 7: 775-819. [CrossRef]

Grant, Robert M. 1996. Toward a knowledge based theory of the firm. Strategic Management Journal 17: 109-22. [CrossRef]

Gold, Andrew H., Arvind Malhotra, and Albert H. Segars. 2001. Knowledge management: An organizational capabilities perspective. Journal of Management Information Systems 18: 185-214. [CrossRef]

Gupta, Priya Dhamija, and Sonali Bhattacharya. 2016. Impact of Knowledge Management Processes for Sustainability of Small Family Businesses: Evidences from the Brassware Sector of Moradabad (India). Journal of Information and Knowledge Management 15: 1650040. [CrossRef]

Hair, Joseph F., Rolph E. Anderson, Ronald L. Tatham, and William C. Black. 1998. Multivariate Data Analysis. Upper Saddle River: Prentice-Hall.

Hatak, Isabella, Teemu Kautonen, Matthias Fink, and Juha Kansikas. 2016. Innovativeness and family-firm performance: The moderating effect of family commitment. Technological Forecasting and Social Change 102: 120-31. [CrossRef]

Hernandez, Morela. 2012. Toward an understanding of the psychology of stewardship. Academy of Management Review 37: 172-93. [CrossRef]

Hernández-Linares, Remedios, and María Concepción López-Fernández. 2018. Entrepreneurial orientation and the family firm: Mapping the field and tracing a path for future research. Family Business Review 31: 318-51. [CrossRef]

Hernández-Perlines, Felipe, and Nina Rung-Hoch. 2017. Sustainable Entrepreneurial Orientation in Family Firms. Sustainability 9: 1212. [CrossRef]

Hofstede, Geert. 2001. Culture's Consequences: Comparing Values, Behavior, Institutions, and Organizations across Nations, 2nd ed. Thousand Oaks: Sage Publications.

Hussinki, Henri, Aino Kianto, Mika Vanhala, and Paavo Ritala. 2017. Assessing the universality of knowledge management practices. Journal of Knowledge Management 21: 1596-621. [CrossRef]

Huybrechts, Jolien, Wim Voordeckers, and Nadine Lybaert. 2013. Entrepreneurial risk taking of private family firms: The influence of a nonfamily CEO and the moderating effect of CEO tenure. Family Business Review 26: 161-79. [CrossRef]

Jaskiewicz, Peter, Klaus Uhlenbruck, David B. Balkin, and Trish Reay. 2013. Is nepotism good or bad? Types of nepotism and implications for knowledge management. Family Business Review 26: 121-39. [CrossRef]

Jayasingam, Sharmila, Mahfooz Ansari, T. Ramayah, and Muhamad Jantan. 2013. Knowledge management practices and performance: Are they truly linked? Knowledge Management Research E Practice 11: 255-64. 
Kallmuenzer, Andreas, and Ursula Scholl-Grissemann. 2017. Disentangling antecedents and performance effects of family SME innovation: A knowledge-based perspective. International Entrepreneurship Management Journal 13: 1117-138. [CrossRef]

Kazanjian, Robert K., Robert Drazin, and Mary Ann Glynn. 2010. Creativity and technological learning: The roles of organization architecture and crisis in large-scale projects. Journal of Engineering and Technology Management 17: 273-98. [CrossRef]

Katila, Riitta. 2002. New product search over time: Past ideas in their prime. Academy of Management Journal 45: 995-1010. [CrossRef]

Katila, Riitta, and Gautam Ahuja. 2002. Something old, something new: A longitudinal study of search behaviour and new product introduction. Academy of Management Journal 45: 1183-19.

Kianto, Aino, Paavo Ritala, John-Christopher Spender, and Mika Vanhala. 2014. The interaction of intellectual capital assets and knowledge management practices in organizational value creation. Journal of Intellectual Capital 15: 362-75. [CrossRef]

Kim, Changsu, and Jaeyong Song. 2007. Creating new technology through alliances: An empirical investigation of joint patents. Technovation 27: 461-70. [CrossRef]

Klammer Adrian, Gueldenberg Stefan, Kraus Sascha, and O'Dwyer Michelle. 2017. To change or not to changeAntecedents and outcomes of strategic renewal in SMEs. International Entrepreneurship Management Journal 13: 739-56. [CrossRef]

Kogut, Bruce, and Udo Zander. 1992. Knowledge of the firm, combinative capabilities, and the replication of technology. Organization Science 3: 383-97. [CrossRef]

Kotlar, Josip, Alfredo De Massis, Federico Frattini, Mattia Bianchi, and Hanquing Fang. 2013. Technology Acquisition in Family and Nonfamily Firms: A Longitudinal Analysis of Spanish Manufacturing Firms. Journal of Product Innovation Management 30: 1073-88. [CrossRef]

Kumar, Nirmalya, Louis W. Stern, and James C. Anderson. 1993. Conducting Interorganizational Research Using Key Informants. Academy of Management Journal 36: 1633-51.

Lawson, Benn, Kenneth J. Petersen, Paul D. Cousins, and Robert B. Handfield. 2009. Knowledge sharing in interorganizational product development teams: The effect of formal and informal socialization mechanisms. Journal of Product Innovation Management 26: 156-72. [CrossRef]

Lee, Voon-Hsien, Lai-Ying Leong, Teck-Soon Hew, and Keng-Boon Ooi. 2013. Knowledge management: A key determinant in advancing technological innovation? Journal of Knowledge Management 17: 848-72. [CrossRef]

Letonja, Marina, and Mojca Duh. 2016. Knowledge trasnfer in family businesses and its effects on the innovativeness of the next family generation. Knowledge Management Research \& Practice 14: 213-24.

Li, Haiyang, and Kwaku Atuahene-Gima. 2001. Product innovation strategy and performance of new technology ventures in China. Academy of Management Journal 44: 1123-34.

Li, Yuan, Xunfeng Liu, Longwei Wang, Mingfang Li, and Hai Guo. 2009. How Entrepreneurial Orientation Moderates the Effects of Knowledge Management on Innovation. Systems Research and Behavioral Science 26: 645-60. [CrossRef]

Li, Ling, and Xiping Zhao. 2006. Enhancing competitive edge through knowledge management in implementing ERP systems. Systems Research and Behavioral Science 23: 129-40. [CrossRef]

Li, Yuan, Yi Liu, and Yongbin Zhao. 2006. The role of market and entrepreneurship orientation and internal control in the new product development activities of Chinese firms. Industrial Marketing Management 35: 336-47. [CrossRef]

Lin, Bou-Wen, and Chung-Jen Chen. 2006. Fostering product innovation in industry networks: The mediating role of knowledge integration. International Journal of Human Resource Management 17: 155-73. [CrossRef]

Lumpkin, G. Tom, and Gregory G. Dess. 1996. Clarifying the Entrepreneurial Orientation Construct and Linking It to Performance. Academy of Management Review 21: 135-72. [CrossRef]

Lumpkin, G. Thomas, and Gregory G. Dess. 2001. Linking two dimensions of entrepreneurial orientation to firm performance: The moderating role of environment and industry life cycle. Journal of Business Venturing 16: 429-51. [CrossRef]

Madanoglu, Melih, Levent Altinay, and Xuan Lorna Wang. 2016. Disentangling the effect of family involvement on innovativeness and risk-taking: The role of decentralization. Journal of Business Research 69: 1796-800. [CrossRef] 
Mascarenhas, Briance. 1985. Flexibility: Its relationship to environmental dynamism and complexity. International Studies of Management $\mathcal{E}$ Organization 14: 107-24.

Matsuo, Makoto. 2015. A framework for facilitating experiential learning. Human Resource Development Review 14: 442-61. [CrossRef]

Messeni Petruzzelli, Antonio, Vito Albino, Nunzia Carbonara, and Daniele Rotolo. 2010. Leveraging learning behavior and network structure to improve knowledge gatekeepers' performance. Journal of Knowledge Management 14: 635-58. [CrossRef]

Miller, Danny. 1983. The Correlates of Entrepreneurship in Three Types of Firms. Management Science 29: 770-91. [CrossRef]

Miller, Danny, Lloyd Steier, and Isabelle Le Breton-Miller. 2016. What can scholars of entrepreneurship learn from sound family businesses. Entrepreneurship Theory and Practice 40: 445-55. [CrossRef]

Mustafa, Michael, Erik Lundmark, and Hazel Melanie Ramos. 2016. Untangling the relationship between human resource management and corporate entrepreneurship: The mediating effect of middle managers' knowledge sharing. Entrepreneurship Research Journal 6: 273-95. [CrossRef]

Nieto, Maria Jesus, Lluis Santamaria, and Zulima Fernandez. 2015. Understanding the Innovation Behavior of Family Firms. Journal of Small Business Management 53: 382-99. [CrossRef]

Norrgren, Flemming, and Joseph Schaller. 1999. Leadership style: Its impact on cross-functional product performance. Journal of Product Innovation Management 16: 377-84. [CrossRef]

Nunnally, Jum C. 1978. Psychometric Theory. New York: McGraw-Hill.

Manual, Oslo. 2005. Proposed Guidelines for Collecting and Interpreting Technological Innovation Data: The Oslo Manual. Paris: Organization for Economic Development and Co-Operation.

Lotti Oliva, Fabio. 2014. Knowledge management barriers, practices and maturity model. Journal of Knowedge Management 18: 1053-74. [CrossRef]

Patel, Pankaj C., and James O. Fiet. 2011. Knowledge Combination and the Potential Advantages of Family Firms in Searching for Opportunities. Entrepreneurship Theory and Practice 35: 1179-97. [CrossRef]

Pearson, Allison W., Jon C. Carr, and John C. Shaw. 2008. Toward a theory of familiness: A social capital perspective. Entrepreneurship Theory and Practice 32: 949-69. [CrossRef]

Pittino, Daniel, Ascensión Barroso-Martínez, Francesco Chirico, and Ramón Sanguino-Galván. 2018. Psychological ownership, knowledge sharing and entrepreneurial orientation in family firms: The moderating role of governance heterogeneity. Journal of Business Research 84: 312-26. [CrossRef]

Purvis, Russell L., Vallabh Sambamurthy, and Robert W. Zmud. 2001. Assimilation of knowledge platforms in organizations: An empirical investigation. Organization Science 12: 117-35. [CrossRef]

Sethi, Rajesh, and Anju Seth. 2009. Can quality-oriented firms develop innovative new products? Journal of Product Innovation Management 26: 206-21. [CrossRef]

Rauch, Andreas, Johan Wiklund, G. Tom Lumpkin, and Michael Frese. 2009. Entrepreneurial orientation and business performance: An assessment of past research and suggestions for the future. Entrepreneurship Theory and Practice 33: 761-87. [CrossRef]

Ren, Yuqing, Kathleen M. Carley, and Linda Argote. 2006. The contingent effects of transactive memory: When is it more beneficial to know what others know? Management Science 52: 671-82. [CrossRef]

Roberts, Peter W., and Raphael Amit. 2003. The dynamics of innovative activity and competitive advantage: The case of Australian retail banking, 1981 to 1995. Organization Science 14: 107-22. [CrossRef]

Roed, Irina. 2016. Disentangling the family firm's innovation process: A systematic review. Journal of Family Business Strategy 7: 185-201. [CrossRef]

Saha, Kaustav, Rohit Kumar, Swarup Kumar Dutta, and Tanusree Dutta. 2017. A content adequate five-dimensional entrepreneurial Orientation. Journal of Business Venturing 8: 41-49. [CrossRef]

Serrano-Bedia, Ana M., M. Concepción López-Fernández, and Gema Garcia-Piqueres. 2016. Analysis of the relationship between sources of knowledge and innovation performance in family firms. Innovation 18: 489-512. [CrossRef]

Serrano-Bedia, Ana M., M. Concepción López-Fernández, Gema García-Piqueres, and María Obeso. 2018a. The role of family firm on the relationship between KMP and innovation. Paper presented at the 13th European Conference on Innovation and Entrepreneurship, ECIE, Aveiro, Portugal, September 20-21. 
Serrano-Bedia, Ana M., Manuel Palma-Ruiz, and Cinthya Flores-Rivera. 2018b. Innovation and Family Firms: Past and Future Research Perspectives. In Handbook of Research on Entrepreneurial Leadership and Competitive Strategy in Family Business. Hershey: IGI Global.

Sirmon, David G., Michael A. Hitt, R. Duane Ireland, and Brett Anitra Gilbert. 2011. Resource Orchestration to Create Competitive Advantage Breadth, Depth, and Life Cycle Effects. Journal of Management 37: 1390-412. [CrossRef]

Sirmon, David G., and Michael A. Hitt. 2003. Managing resources: Linking unique resources, management, and wealth creation in family firms. Entrepreneurship Theory and Practice 27: 339-58. [CrossRef]

Spender, J.-C. 1996. Making knowledge the basis of a dynamic theory of the firm. Strategic Management Journal 17: 45-62. [CrossRef]

Stanovcic, Tatjana, Sanja Pekovic, and Amira Bouziri. 2015. The effect of knowledge management on environmental innovation. The empirical evidence from France. Baltic Journal of Management 10: 413-31. [CrossRef]

Subramaniam, Mohan, and Mark A. Youndt. 2005. The influence of intellectual capital on the types of innovation capabilities. Academy of Management Journal 48: 450-63. [CrossRef]

Tabachnick, Barbara G., and Linda S. Fidell. 2012. Using Multivariate Statistics, 6th ed. Boston: Pearson Education.

Teng, Bing-Sheng. 2007. Corporate entrepreneurship activities through strategic alliances: A resource-based approach toward competitive advantage. Journal of Management Studies 44: 119-42. [CrossRef]

Thornhill, Stewart. 2006. Knowledge, innovation and firm performance in high- and low-technology regimes. Journal of Business Venturing 21: 687-703. [CrossRef]

Tushman, Michael, and David Nadler. 1986. Organization for innovation. California Management Review 28: 74-92. [CrossRef]

Van de Ven, Andrew H. 1986. Central problems in the management of innovation. Management Science 32: 590-607. [CrossRef]

Vandekerkhof, Pieter, Tensie Steijvers, Walter Hendriks, and Wim Voordeckers. 2015. The Effect of Organizational Characteristics on the Appointment of Nonfamily Managers in Private Family Firms. Family Business Review 28: 104-22. [CrossRef]

Wiklund, Johan, and Dean Shepherd. 2003. Knowledge-based resources, entrepreneurial orientation, and the performance of small and medium-sized businesses. Strategic Management Journal 24: 1307-14. [CrossRef]

Woodfield, Paul, and Kenneth Hust. 2017. Intergenerational knowledge sharing in family firms: Case-based evidence from the New Zealand wine industry. Journal of Family Business Strategy 8: 57-69. [CrossRef]

Yusr, Maha Mohammed, Sany Sanuri Mohd Mokhtar, Abdul Rahim Othman, and Yaty Sulaiman. 2017. Does interaction between TQM practices and knowledge management processes enhance the innovation performance? International Journal of Quality \& Reliability Management 34: 955-74.

Zack, Michael, James McKeen, and Satyendra Singh. 2009. Knowledge management and organizational performance: An exploratory survey. Journal of Knowledge Management 13: 392-409. [CrossRef]

Zahra, Shaker A., and Gerard George. 2002. Absorptive capacity: A review, reconceptualization, and extension. Academy of Management Review 27: 185-203. [CrossRef]

Zahra, Shaker A., Donald O. Neubaum, and Bárbara Larrañeta. 2007. Knowledge sharing and technological capabilities: The moderating role of family involvement. Journal of Business Research 60: 1070-979. [CrossRef]

(C) 2019 by the authors. Licensee MDPI, Basel, Switzerland. This article is an open access article distributed under the terms and conditions of the Creative Commons Attribution (CC BY) license (http://creativecommons.org/licenses/by/4.0/). 